TABLEAU II.

Taux d'iode des cultures en lait $(100 \mathrm{ml})$ d'une même souche de Bact. aerogenes à $37^{\circ}$

\begin{tabular}{|c|c|c|c|c|c|}
\hline \multicolumn{2}{|c|}{2 jours } & 4 jours & 6 jours & 8 jours & 10 jours \\
\hline A. & 6,42 & 6,66 & 10,89 & 13,84 & 16,87 \\
\hline B. & 6,17 & 6,86 & 14,23 & 19,76 & 27,18 \\
\hline
\end{tabular}

On voit que les chiffres absolus ont très peu de valeur. Le principe de la méthode repose tout simplement sur le fait que les cultures en lait de Bact. aerogenes ont toujours un chiffre de fixation d'iode bien plus élevé que le témoin stérile, tandis que les chiffres des cultures de Bact. coli restent au voisinage de celui-ci.

Je ne peux pas encore me prononcer d'une façon définitive sur la nature des corps réagissant avec l'iode qui se forment dans les cultures en lait de Bact. aerogenes. Toutefois, comme ce microbe produit des quantités très notables d'acétylméthylcarbinol dans le lait, il est bien probable que ce corps entre aussi pour une large part dans la réaction avec l'iode.

La réaction de Voghs-Proskauer se base aussi sur la présence, dans du bouillon dextrosé, de l'acétylméthylearbinol. Notre réaction peut donc servir en quelque sorte comme contrôle de la réaction Voges-Proskader et devenir ainsi encore une preuve dans la différenciation parfois assez difficile entre Bact. coli et Bact. aerogenes.

\title{
L'ACIDIFICATION PROLONGÉE DU PETIT-LAIT (1)
}

\author{
par
}

\section{le Professeur Dr Otakar LAXA}

Directeur de l'Institut lactologique à l'Ecole polytechnique à Prague.

C'est une chose connue que l'acidification spontanée du petit-lait se fait plus lentement que celle du lait lui-même, phénomène qu'on peut expliquer par le manque de caséine, qui, dans le cas du lait, s'unit à une partie de l'acide lactique de telle manière que les bactéries ácidifiantes trouvent ainsi le liquide plus apte à la transformation du lactose. Et pourtant le petit-lait peut atteindre après une longue période, une acidité remarquable, comme le montre l'exemple suivant.

Une bouteille de 10 litres remplie jusqu'au bouchon de petit-

(1) Paru dans lo Volume jubilaire du Professeur Ch. Porcher. 
lait pasteurisé et acidifié par une culture de Bacterium lactis acidi a été laissée pendant 10 ans dans un lieu sombre, à la température ordinaire. Pendant ce temps, on pouvait observer que la surface du liquide sous le bouchon, au commencement très nette, s'était couverte plus tard d'une végétation de mycodermes. Le liquide, qui au début avait l'odeur du lait aigri, prenait plus tard celle de l'éther acétique pour acquérir après 5 années une odeur d'acétone.

Après ces 10 années, on voulut utiliser la bouteille et on l'a vidée. A ce moment, j'ai analysé ce petit-lait. Une acidité de $96^{\circ}$ SoxhletHenkel correspondant à un taux de $2,16 \%$ d'acide lactique fut trouvée. L'analyse a démontré que le lactose avait disparu et s'était transformé en acide lactique et en une petite quantité d'acides volatils et d'alcools ; une petite quantité de lactose avait même fermenté jusqu'à transformation en acide carbonique, peut-être sous l'action des mycodermes. Le résidu sec, qui était au commencement de $6,2 \%$, s'abaissait après 10 années au chiffre de $2,94 \%$.

$\mathrm{Vu}$ que la littérature affirme que le Bacterium lactis acidi ne peut former dans le lait que $1 \%$ d'acide lactique et qu'une acidité plus élevée est nuisible aux cellules de ces bactéries, j'ai estimé le cas cité comme intéressant et susceptible d'une étude plus approfondie. C'est pourquoi j'ai fait une expérience avec le petit-lait fermenté par le Bacterium lactis acidi en éliminant la possibilité de l'infection des bactéries du groupe du Bacterium bulgaricum, qui peuvent facilement élever l'acidité du lait au-dessus de $1 \%$.

Quatre litres de petit-lait préparé avec du lait précipité par la présure étaient stérilisés et versés dans une bouteille à bouchon de verre. Le petit-lait était, après refroidissement, ensemencé avec une culture de Bacterium lactis acidi. J'ai versé à la surface du liquide une épaisse couche de paraffine liquide pour écarter le développement des mycodermes et des moisissures. La bouteille était conservée dans une partie sombre de la pièce et on en a déterminé l'acidité de temps en temps. Voilà les chiffres obtenus :

TABLEAU I.

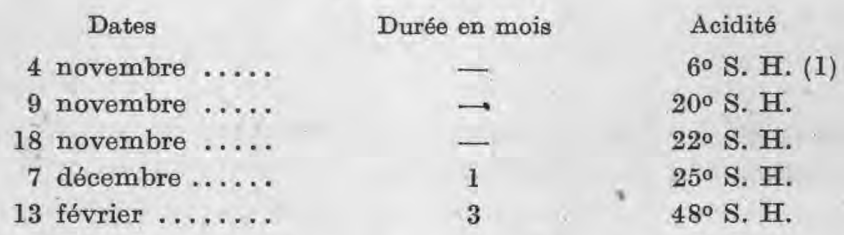

(1) En degrés Soxhlet-Henkel.

On voit que pour obtenir une acidité de $25^{\circ} \mathrm{S}$. H., acidité que peut atteindre le lait placé dans les mêmes conditions de 14 heures, il a fallu un mois pour le petit-lait. 
Après 3 mois, j'ai partagé le liquide entre 2 bouteilles, j'en ai laissé une sans changement, veillant seulement à ce que la couche de paraffine soit suffisante. Dans une autre bouteille, j'ai versé une petite quantité $\left(5 \mathrm{~cm}^{3}\right)$ d'une solution d'iodoforme dans l'acétone et j'ai mis aussi à la surface une couche de paraffine liquide.

Le petit-lait original était troublé par les restes de la paracaséine et du lait caillé de la culture ajoutée. Ces matières se sont déposées pendant les premiers 3 mois, et le liquide était limpide. J'ai prélevé une partie de ce petit-lait absolument limpide avec une pipette dans unflacon ayant un bouchon de verre, mais sans addition d'acétone iodoformé, en versant à la surface la paraffine liquide.

L'acidité a montré plus tard les chiffres suivants :

TABLEAU II.

\begin{tabular}{|c|c|c|c|c|}
\hline Date & $\begin{array}{c}\text { Durée en } \\
\text { mois }\end{array}$ & Originel & $\begin{array}{l}\text { Petit-lait } \\
\text { limpide }\end{array}$ & $\begin{array}{l}\text { Conservé par } \\
\text { iodoforme }\end{array}$ \\
\hline $1 \ldots \ldots$ & 5 & $60^{\circ} \mathrm{S} . \mathrm{H}$. & - s. H. & $74^{\circ} \mathrm{S} . \mathrm{H}$. \\
\hline 29 mai ........ & $63 / 4$ & $80^{\circ}$ s. H. & $60^{\circ}$ S. H. & $87^{\circ} \mathrm{S} . \mathrm{H}$. \\
\hline 24 juillet. & $83 / 4$ & $88^{\circ} \mathrm{S}$. H. & $64^{\circ}$ S. H. & $78^{\circ} \mathrm{S} . \mathrm{H}$. \\
\hline
\end{tabular}

Des cultures sur gélatine de petit-lait avec addition de carbonate de chaux, ensemencées par le petit-lait des expériences, ont donné plusieurs colonies de bactéries et de moisissures, mais on ne pouvait pas déceler les colonies des bactéries lactiques, caractérisées par une zone limpide. C'est pourquoi j'ai ensemencé $0,05-1 \mathrm{~cm}^{3} \mathrm{du}$ petit-lait dans du lait stérilisé, que j'ai gardé deux jours dans une étuve à $37^{\circ} \mathrm{C}$.

J'ai pu juger de l'acidité du lait, à la présence des bactéries lactiques. On pouvait déceler la présence des cellules vivantes dans la bouteille originale, parce que le lait stérilisé et ensemencé était caillé et l'acidité faisait $24^{\circ} \mathrm{S}$. H. Le petit-lait conservé avec l'addition d'iodoforme n'a provoqué dans le lait stérilisé que $10^{\circ}$ d'acidité. De cela, on peut conclure que les bactéries lactiques dans cette bouteille étaient détruites.

Des chiffres de la dernière expérience, il résulte que l'augmentation de l'acidité n'a pas été interrompue par l'addition d'iodoforme. Quoique l'observation bactériologique annonce la destruction des bactéries lactiques, l'acidité monte pourtant de $48^{\circ}$ jusqu'à $87^{\circ}$. On doit penser que la transformation du lactose en acide lactique ne pouvait pas être le fait de cellules bactériennes vivantes. C'est une enzyme, la "lactacidase", qui se trouve dans ces cellules, et qui manifeste ainsi sa présence. C'est ce dont témoignait aussi l'observation du petit-lait limpide sans l'addition d'iodoforme. Alors que dans le petit-lait originel, avec le sédiment des albuminoïdes que contenaient les cellules des bactéries lactiques, l'acidité s'élevait, 
dans le petit-lait limpide, exempt de ces cellules et de lactacidase, l'acidité était restée presque telle qu'elle était au moment de la séparation de cette partie limpide du liquide originel.

De cette expérience, on peut conclure que :

$1^{0}$ Par l'acidification prolongée du petit-lait, provoquée par la fonction du Bacterium lactis acidi, on peut obtenir un liquide qui contient plus de $1 \%$ d'acide lactique ;

$2^{\circ}$ Cette acidification élevée est en partie causée par la fonction biochimique des cellules vivantes, mais surtout par la "lactacidase» des cellules détruites.

\title{
NOTES SUR LA FABRICATION DU YOGHOURT AU TCHAD (1)
}

\author{
par \\ JACQUES ALLARD.
}

Les essais effectués sur des laits indigènes de cette région (Fort-Lamy) ont donné les résultats qui vont faire l'objet de cette étude.

Deux tubes à essais de lait stérilisé furent ensemencés le 3 août 1931, respectivement de "bacille bulgare " et de "paralactique ", puis furent fermés à la flamme et expédiés liquides par colis postal, via la Nigeria anglaise, à Fort-Lamy.

Les tubes de ferments arrivèrent à destination vers le 25 septembre, coagulés régulièrement, bien que la température favorable de culture $\left(40\right.$ à $45^{\circ}$ C.) n'ait pas été atteinte pendant le voyage. Dès leur arrivée, l'expérimentateur bénévole commenęa ses essais de fabrication, d'abord pour sa consommation personnelle. Il prit un litre propre, et le stérilisa par ébullition sur un bain-marie et selon les moyens de fortune dont il disposait, il recueillit proprement le lait de la traite et malgré les difficultés matérielles de bien stériliser les récipients, le fit bouillir.

A $45^{\circ}$ C., température favorable de culture des ferments, le litre de lait étant resté soigneusement bouché, l'opérateur brisa les deux tubes et versa leur contenu dans la bouteille, agita celle-ci et la boucha, puis, après s'être assuré que la température ambiante resterait constante pendant 8 à 10 heures, il déposa la bouteille à la température atmosphérique, qui est, à cette époque de l'année, comprise entre $+30^{\circ}$ et $+35^{\circ}$, à l'abri des rayons solaires.

(1) Les renseignements locaux et les échantillons ont été fournis par M. Georges DELUz, ingénieur agricole, commis des Services civils, à Fort-Iamy. 